\title{
Role of wetland plants and use of ornamental flowering plants in constructed wetlands for wastewater treatment: a review
}

\author{
Luis Carlos Sandoval-Herazo ${ }^{1-2}$, Josè Luis Marín-Muñiz ${ }^{3 *}$, María Graciela Hernández y Orduñas ${ }^{1}$, \\ \& Antonio Janoary Aleman-Chang ${ }^{1}$ \\ 1 División de Estudios de Posgrados e Investigación, Tecnológico Nacional de México/Instituto Tecnológico \\ de Orizaba, Oriente 9, Emiliano Zapata Sur, C.P. 94320 Orizaba, Veracruz, México;lcsandovalh@gmail.com \\ (L.C.S.-H.). \\ 2 División de Estudios de Posgrados e Investigación, Tecnológico Nacional de México/Instituto Tecnológico \\ Superior de Xalapa, Sección 5A Reserva Territorial S/N, Santa Bárbara, 91096 Xalapa Enríquez, Veracruz, \\ México; lcsandovalh@gmail.com (L.C.S-H.); Graciela.hernandez@itsx.edu.mx (M.G.H-O.); \\ itsx.antonio@yahoo.com.mx (A.J.A-C.). \\ 2 Department of Sustainability and Regional Development, El Colegio de Veracruz, Xalapa, Veracruz, Mexico \\ (J.L.M-M). \\ * Correspondence: soydrew@hotmail.com; Tel.: +52-228-162-4680
}

\begin{abstract}
The vegetation in constructed wetlands (CWs) plays an important role in wastewater treatment. Popularly, the common emergent plants in CWs have been vegetation of natural wetlands. However, there are ornamental flowering plants that have some physiological characteristics similar to the plants of natural wetlands that can stimulate the removal of pollutants in wastewater treatments; such importance in CWs is described here. A literature survey of $87 \mathrm{CWs}$ from 21 countries showed that the four most commonly used flowering ornamental vegetation genera were Canna, Iris, Heliconia and Zantedeschia. In terms of geographical location, Canna spp. is commonly found in Asia, Zantedeschia spp. is frequent in Mexico (a country in North America), Iris is most commonly used in Asia, Europe and North America, and species of the Heliconia genus are commonly used in Asia and parts of the Americas (Mexico, Central and South America). This review also compares the use of ornamental plants versus natural wetland plants and systems without plants for removing pollutants (COD, BOD, nitrogen and phosphorous compounds). The removal efficiency was similar between flowering ornamental and natural wetland plants. However, pollutant removal was better when using ornamental plants than in unplanted CWs. The use of ornamental flowering plants in CWs is an excellent option, and efforts should be made to increase the adoption of these system types and use them in domiciliary, rural and urban areas.
\end{abstract}

Keywords: Ornamental flowering plants, constructed wetlands, wastewater, pollutants.

\section{Introduction}

Nowadays, the use of constructed wetlands (CWs) for wastewater treatment is an option widely recognized. This sustainable ecotechnology is based on natural wetland processes for the removal of contaminants, including physical, chemical and biological routes, but in a more controlled environment compared with natural ecosystems $[\underline{1}, \underline{2}, \underline{3}]$. These ecologically engineered systems involve three important components: porous-filter media, microorganism and vegetation [2]. The mechanisms for the transformation of nutrient and organic matter compounds are 
conducted for biofilms of microorganisms formed in the porous media and the rhizosphere zone [4,5]. The media materials (soil, sand, rocks, and gravel) provide a huge surface area for microorganisms to attach, contributing to macrophyte growth, and also act as filtration and/or adsorption medium for contaminants present in the water []. In regards to the vegetation, one of the most conspicuous features of wetlands is the role that plants play in the production of underground organisms (i.e. rot and rhizomes) in order to provide substrate for attached bacteria and oxygenation of areas adjacent to the root, and absorb and adsorb pollutants from water. Nitrogen $(\mathrm{N})$, phosphorus $(\mathrm{P})$ and other impurities are mainly taken up by wetland plants through the epidermis and vascular bundles of the roots, and are further transported upward to the stem and leaves [7]. This provides carbon for denitrification during biomass decomposition and prevents pollutants from being released from sediments $[8,9,10]$. The use of the CWs technology began in Europe during the 1960's. [1], and has been replicated on other continents. The type of vegetation used are plants from natural wetlands, inlcuding Cyperus papyrus, Phragmites australis, Typha and Scirpus spp., which have been evaluated for their positive effects on treatment efficiency for nutrient and organic compounds around the globe $[8,9,11]$. In the Americas, such species are typical in CWs, and are found mainly in the United States, where the technology has been used extensively and is implemented in different rural and urban zones $[\underline{12}, \underline{13}, \underline{14}, \underline{15}, \underline{16}]$. In recent studies (15 years ago), the goal of CWs studies involved an investigation into the use of herbaceous perennial ornamental plants in CWs, including the use of species with different colored flowers to make the systems more esthetic, and therefore, making it more probable for adoption and replication.

This review attempts to study the role of macrophytes in CWs and highlights the use of ornamental flowering plants in this type of ecotechnology around the world. This includes plants that are not typical in natural wetlands, and shows the resulting removal efficiency and their importance in rural communities. The aim of this study is to create a context regarding the advantages that the use of CWs with ornamental flowering plants provides, emphasizing that these systems could be used for more sites that require wastewater treatment. The information from 87 constructed wetlands using ornamental flowering plants (OFP) in 21 countries was reported in the literature that was analyzed. Only published or accepted (in press) papers were considered; the results of theses or abstracts of conferences were not considered.

\section{Role of macrophytes in CWs}

The plants that grow in constructed wetlands have several properties related to the water treatment process that make them an essential component of the design. Macrophytes are the main source of oxygen in CWs through a process that occurs in the root zone, called radial oxygen loss (ROL) [17]. The ROL contributes to the removal of pollutants because it favors an aerobic micro-environment, and waste removal is therefore accelerated, whereas in anaerobic conditions (the main environment in CWs) there is less pollutant removal. In a recent study [18] comparing the use of plants in high density (32 plants $\mathrm{m}^{-2}$ ) and low density (16 plants $\left.\mathrm{m}^{-2}\right) \mathrm{CWs}$, the removal of nitrogen compounds in high density CWs was twice that of CWs using a low density of plants, which is strong evidence of the importance of plants in such systems. The removal rate of total nitrogen (TN) and total phosphorous (TP) were also positively correlated with the ROL of wetland plants, according to a study involving 35 different species [19].

The roots of plants are the site of many microorganisms because they provide a source of microbial attachment [] $]$ and release exudates, an excretion of carbon that contributes to the denitrification process. This is exudates a necessary source of carbon, which increases the removal of pollutants in anoxic conditions [20,21]. Other physical effects of root structure on CWs includes a reduction in the velocity of water flow, promotion of sedimentation, decreased resuspension, prevention of medium clogging and improved hydraulic conductivity [5,2]. A 5 year study evaluated the influence of vegetation on sedimentation and resuspension of soil particles in small 
CWs [22]. The author showed that macrophytes stimulated sediment retention by mitigating the resuspension of the $\mathrm{CWs}^{\prime}$ sediment (14 to $\left.121 \mathrm{~kg} \mathrm{~m}^{-2}\right)$. Macrophytes increased the hydraulic efficiency by reducing short-circuit or preferential flow. Plant presence led to decrease saturated hydraulic conductivity in horizontal subsurface flow. This study was imperative, since monitoring macrophytes is essential for understanding and controlling clogging in CWs [23].

The removal of organic and inorganic pollutants in CWs is not only the role of microorganisms. This function is also exerted by plants, which are able to tolerate high concentrations of nutrients and heavy metals, and in some cases, plants are able to accumulate them in their tissues [24]. It has been estimated that between 15 and $32 \mathrm{mg} \mathrm{g}^{-1}$ of TN and 2-6 $\mathrm{mg} \mathrm{g}^{-1}$ (dry mass) of TP are removed by CW plants, which was measured in the aboveground biomass $[\underline{25}, \underline{26}]$.

Other uptakes of xenobiotic compounds (organic pollutants) are also the result of the presence of plants, involving processes such as transformation, conjugation and compartmentation [24].

\section{Survey results of use of ornamental flowering plants in CWs}

Table 1 lists examples of ornamental plants used in CWs around the world that were designed for the removal of various types of wastewater. OFP have been used in some countries, particularly in Mexico and China. In China, the most popular vegetation used is Canna sp., while in Mexico the ornamental plant used is more diverse, including plants with flowers in different colors, shapes and aromatic characteristics (Canna, Heliconia, Zantedeschia, Strelitzia spp).

Table 1. Examples of ornamental plants used for CWs designed for the removal of various types of wastewater around the globe.

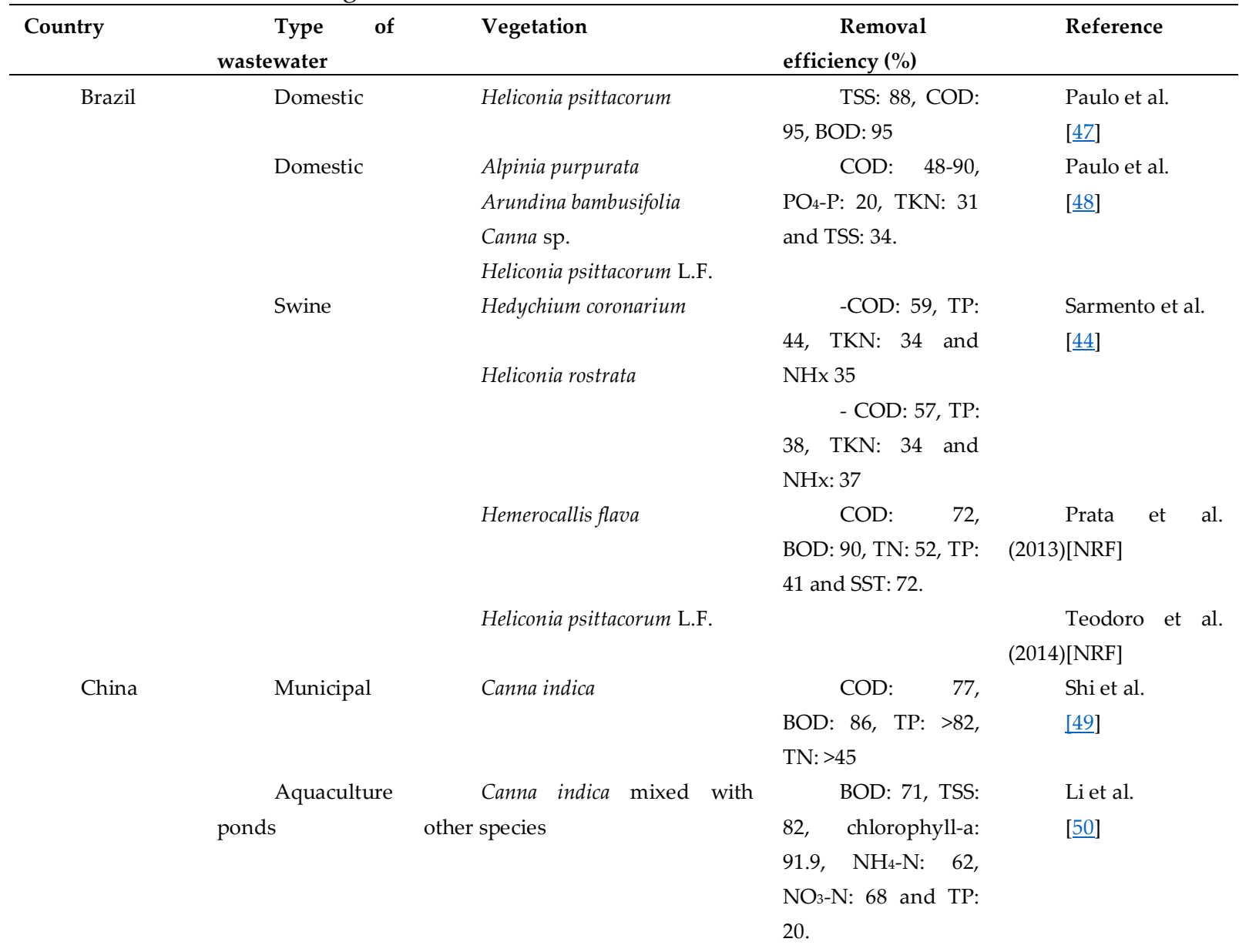


Domestic Canna indica Linn

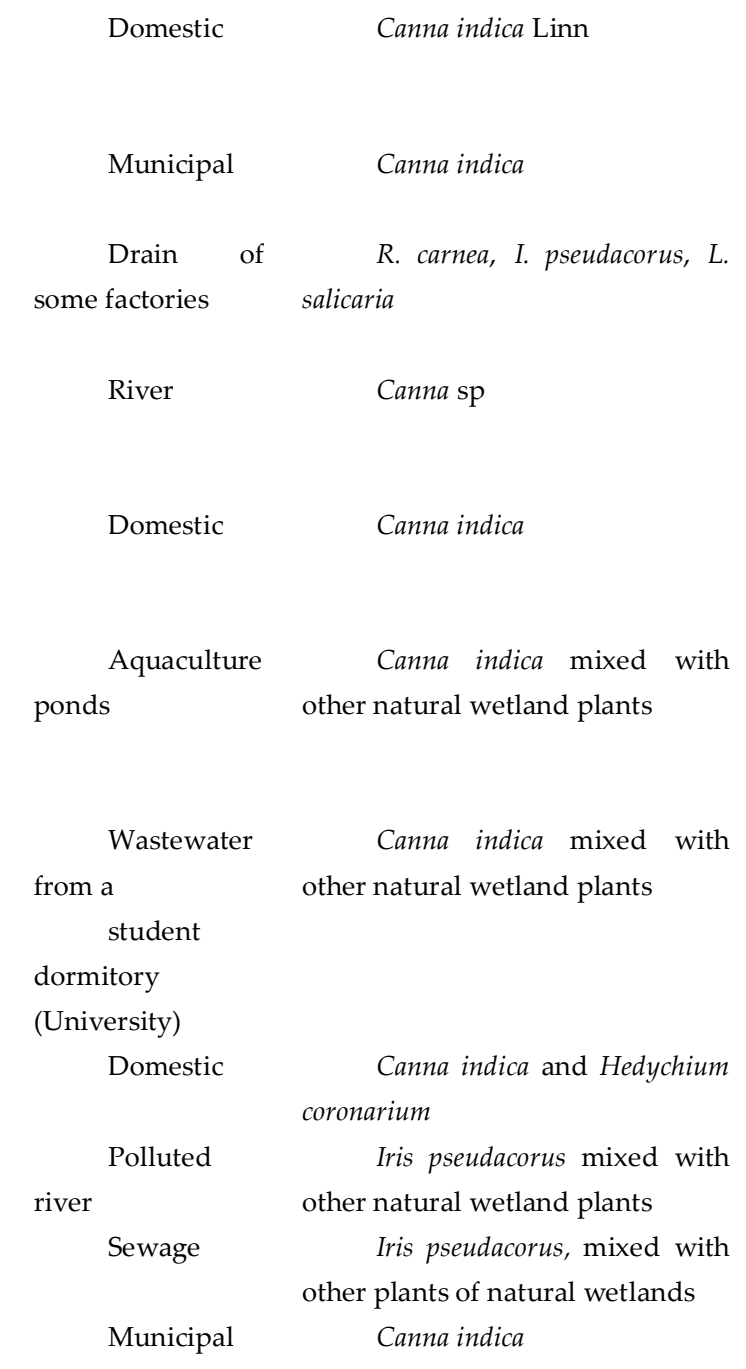

Simulated
polluted river

water

Synthetic

Simulated

polluted river

water

Synthetic

Synthetic

(hydrophonic sol.)

Chile

Zantedeschia aethiopica, Canna
Sewage
spp. and Iris spp
Sewage
pseudacorushia violácea, and Iris

Ww rural Zantedeschia aethiopica community

Colombia

Iris sibirica

Canna indica L.
COD: 82.31 , BOD: 88.6, TP: $>80$, TN: $>85$

$$
\mathrm{NH}_{4}-\mathrm{N}: \quad 99, \quad \text { Zhang et al. }
$$

PO4-P: 87

[드]

Zhang et al. BOD: 60-90TN: [프]

60-92, TP: 50-97,

COD: 95, Sun et al.

$\mathrm{N}-\mathrm{NH}_{4}:$ : 100, N-NO

76, TN: 72

$\begin{array}{lrl}\text { TP: } & 60, & \text { Cui et al. } \\ \mathrm{NH}_{4}-\mathrm{N}: \text { 30-70, } & \text { TN: } & {[\underline{55}]} \\ 25 & & \\ \text { BOD: } & 56, & \text { Zhang et al. } \\ \text { COD: } 26, \text { TSS: } 58, & {[56]}\end{array}$

TP: $17, \mathrm{TN}: 48$ and

$\mathrm{NH}_{4}-\mathrm{N}: 34$.

COD: 50-70,

Qiu et al. BOD: $60-80, \mathrm{~N}-\mathrm{NO}_{3}$ : 65-75, TP: 50-80

[57]

$$
\text { TP: 40-70 }
$$

Wen et al.

[58]

TN: 68 , NH4-N:93, TP: 67

TN: 20 and TP:

44

COD: 60 , $\mathrm{NO}_{3}-\mathrm{N}: \quad 80, \mathrm{TN}: 15$, TP:52

COD: 22, TN: 46, $\mathrm{NH}_{4}-\mathrm{N}:$ 62, TP: 58

Fluoride: 51, Arsenic: 95

Cd: 92

N: $56-60$

Wu et al.

[59]

Xie et al.

[60]

Chang et al.

[61]

Gao et al.

[62]

Li et al.

[39]

Gao et al.

[63]

Hu et al.

[64]

TN: 40-60, N-NO3: 20-95,

$\mathrm{NH}_{4}-\mathrm{N}$ : 20-55

BOD: $82, \mathrm{TN}$ : 53, TP: 60 .

BOD: 57-88,

COD: 45-72, TSS:

70-93, PO4-P: 6-20.

Organic

matter: $60 \%$, TSS:

$90 \%$

Wang et al.

[65]

Morales et al.

[66]

Burgos et al.

[67]

Leyva et al.

[29]

$\mathrm{NH}_{3}: 57$ 


\begin{tabular}{|c|c|c|c|c|}
\hline & & & COD: 70 & $\begin{array}{l}\text { uera and Peña-Varón } \\
\qquad 68]\end{array}$ \\
\hline & $\begin{array}{r}\text { Synthetic } \\
\text { landfill leachate }\end{array}$ & Heliconia psittacorum & $\begin{array}{c}\mathrm{COD}, \quad \mathrm{TKN} \\
\left.\text { and } \mathrm{NH}_{4} \text { (all: } 65-75\right)\end{array}$ & Madera-Parra et \\
\hline & & & & [69] \\
\hline & Cattle bath & Alpinia purpurata & SST: 58, TP: 85 & Marrugo-Negret \\
\hline & & & COD: 63 & e et al. [70] \\
\hline & Municipal & Heliconia psitacorum & $\begin{array}{l}\text { Bisphenol } \\
\text { A:73, Nonylphenols: } \\
63\end{array}$ & Toro-Vélez et al. \\
\hline Costa Rica & $\begin{array}{l}\text { Dairy raw } \\
\text { manure }\end{array}$ & $\begin{array}{l}\text { Ludwigia inucta, Zantedechia } \\
\text { aetiopica, Hedychium coronarium } \\
\text { and Cannageneralis }\end{array}$ & 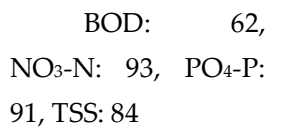 & $\begin{array}{l}\text { León and } \\
\text { Cháves } \\
\text { [72] }\end{array}$ \\
\hline \multirow[t]{4}{*}{ Egypt } & Municipal & Canna sp & TSS: 92, COD: & Abou-Elela and \\
\hline & & & 88, BOD: 90 & $\begin{array}{l}\text { Hellal } \\
\qquad[73]\end{array}$ \\
\hline & Municipal & Canna sp & TSS: 92, COD: & Abou-Elela et al. \\
\hline & & & 92, BOD: 92 & [74] \\
\hline \multirow[t]{9}{*}{ India } & Paper mill & Canna indica & 9,10,12,13-tetr & Choudhary et al. \\
\hline & effluent & & $\begin{array}{l}\text { achlor- ostearic acid: } \\
92 \quad \text { and } \\
\text { 9,10-dichlorostearic } \\
\text { acid: } 96\end{array}$ & [75] \\
\hline & Synthetic & Canna indica & $\begin{array}{l}\text { Dye: } 70-90 \\
\text { COD: } 75\end{array}$ & $\begin{array}{l}\text { Yadav et al. } \\
\text { [76] }\end{array}$ \\
\hline & $\begin{array}{l}\text { Synthetic } \\
\text { greywater }\end{array}$ & Heliconia angusta & $\begin{array}{l}\text { COD:40, BOD: } \\
\text { 70, TSS: 62, TDS: } 19\end{array}$ & Saumya et al. \\
\hline & Domestic & Canna generalis & TN: 52, T-PO3: & Ojoawo et al. \\
\hline & & & 9 & [78] \\
\hline & $\begin{array}{l}\text { Collection } \\
\text { pond }\end{array}$ & Canna Lily & $\begin{array}{r}\text { BOD: } 70-96, \\
\text { COD: } 64-99\end{array}$ & [79] Haritash et al. \\
\hline & $\begin{array}{l}\text { Hostel } \\
\text { greywater }\end{array}$ & Canna indica & $\begin{array}{l}\text { COD, TKN } \\
\text { and Pathogen all up } \\
70\end{array}$ & $\begin{array}{r}\text { Patil and } \\
\text { Munavalli, } \\
\text { [80] }\end{array}$ \\
\hline & Domestic & Polianthus tuberosa L. & $\begin{array}{l}\text { Heavy metals } \\
(\mathrm{Pb} \text { and } \mathrm{Fe}: 73-87), \\
(\mathrm{Cu} \text { and } \mathrm{Zn}: 31-34) \\
\text { and } \mathrm{Ni} \text { and } \mathrm{Al}: 20-26\end{array}$ & $\begin{array}{c}\text { Singh and } \\
\text { Srivastava } \\
{[81]}\end{array}$ \\
\hline Ireland & Domestic & Iris pseudacorus & TN: $30, \mathrm{TP}: 28$ & $\begin{array}{c}\text { Gill and } \\
\text { O'Luanaigh } \\
{[82]}\end{array}$ \\
\hline Italy & Synthetic & $\begin{array}{l}\text { Zantedeschia aethiopica, Canna } \\
\text { indica }\end{array}$ & $\begin{array}{l}\text { N: 65-67, P: } \\
\text { 63-74, Zn and Cu: } \\
\text { 98-99, } \\
\text { Carbamazepine: } \\
\text { 25-51, LAS: 60-72 }\end{array}$ & $\begin{array}{l}\text { Macci et al. } \\
\text { [83] }\end{array}$ \\
\hline Kenya & Flower farm & Canna sp & $\begin{array}{l}\text { BOD: } 87, \\
\text { COD: } 67, \text { TSS: } 90, \\
\text { TN: } 61\end{array}$ & $\begin{array}{l}\text { Kimani et al. } \\
{[84]}\end{array}$ \\
\hline \multirow[t]{3}{*}{ Mexico } & Municipal & Zantedeschia aethiopoca & COD: 35, TN: & Belmont and \\
\hline & & & 45.6 & $\begin{array}{l}\text { Metcalfe } \\
{[85]}\end{array}$ \\
\hline & Domestic & $\begin{array}{l}\text { Zantedeschia } \\
\text { Aethiopica and }\end{array}$ & 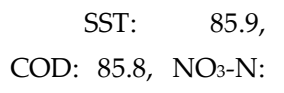 & $\begin{array}{l}\text { Belmont et al. } \\
{[86]}\end{array}$ \\
\hline
\end{tabular}


Canna flaccida

Coffee proce
Domestic

Domestic

Wastewater form canals

\begin{tabular}{|c|c|}
\hline Municipal & $\begin{array}{l}\text { Strelitzia reginae, Anthurium, } \\
\text { andreanum. }\end{array}$ \\
\hline Groundwat & $\begin{array}{l}\text { Zantedeschia aethiopica and } \\
\text { Anemopsis californica }\end{array}$ \\
\hline Domestic & Gladiolus spp \\
\hline $\begin{array}{r}\text { Mixture of } \\
\text { gray water (from a }\end{array}$ & $\begin{array}{l}\text { Zantedeschia aethiopica and } \\
\text { Canna indica }\end{array}$ \\
\hline $\begin{array}{l}\text { cafeteria and } \\
\text { research }\end{array}$ & \\
\hline laboratories) & \\
\hline Domestic & Zantedeschia aethiopica \\
\hline Domestic & $\begin{array}{l}\text { Heliconia stricta, Heliconia } \\
\text { psittacorum and Alpinia purpurata }\end{array}$ \\
\hline Municipal & $\begin{array}{l}\text { Canna hybrids and Strelitzia } \\
\text { reginae }\end{array}$ \\
\hline Municipal & $\begin{array}{l}\text { Zantedeschia aethiopica and } \\
\text { Strelitzia reginae }\end{array}$ \\
\hline Domiciliar & Spathiphyllum \\
\hline & $\begin{array}{l}\text { Zantedechia aethiopica, Iris japonica, } \\
\text { Hedychium coronarium, Alocasia sp, } \\
\text { Heliconia sp. and Strelitzia reginae. }\end{array}$ \\
\hline Community & $\begin{array}{l}\text { Zantedeschia aethiopica, Lilium } \\
\text { sp, Anturium sp and Hedychium } \\
\text { coronarium }\end{array}$ \\
\hline Stillage & Canna indica \\
\hline \multicolumn{2}{|l|}{ Treatment } \\
\hline Artificial & $\begin{array}{l}\text { Iris sibirica and Zantedeschia } \\
\text { aethiopica }\end{array}$ \\
\hline Community & $\begin{array}{l}\text { Alpinia purpurata and } \\
\text { Zantedeschia aethiopica }\end{array}$ \\
\hline Polluted & Zantedeschia aethiopica \\
\hline Municipal & $\begin{array}{l}\text { Spathiphyllum wallisii, } \\
\text { and Zantedeschia aethiopica }\end{array}$ \\
\hline
\end{tabular}

81.7, $\mathrm{NH}_{4}-\mathrm{N}: \quad 65.5$,

NT: 72.6

COD: 91,

Coliformes: 93

COD: $>75, \mathrm{P}:$

66, Coliforms: 99

BOD: 79, TN: 55, PT: 50

COD: 92,

N-NH4: 85, P-PO4: 80 o et al.

TSS: 62, COD: 80, BOD: $82, \mathrm{TP}:>50$, $\mathrm{TN}:>49$

As: $75-78$

Orozco et al.

[87]

Zurita et al.

[45]

Zurita et al.

[88]

Ramírez-Carrill

[89]

Zurita et al.

[90]

Zurita et al.

[91]

BOD: 33 ,

TN:53, TP:75

Castañeda and Flores

[92]

COD: 65, NT: 22.4, PT: 5.

Zurita and White

[93]

BOD: 70

Hallack et al. [94]

BOD: 48 , COD: 64, TP: 39, TN: 39

DQO: $86, \mathrm{NT}$ : 30-33, PT: 24-44

COD: $75, \mathrm{TN}$ : 18, TP: 2, TSS: 88.

Méndez-Mendo za et al. [95]

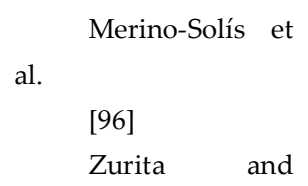
al.

[96]

Zurita and

Carreón-Álvarez

[97]

N-NH4: 64-93

BOD: 22-96

COD: 25-64

NT: 47, PT: 33 ,

COD: 67

Garzón et al.

[98]

Hernández

[46]

BOD:87, COD:70

López-Rivera et al. [99]

Carbamazepin e: 50-65

Tejeda et al. [100]

Marín-Muñiz et al.

[101]

$\mathrm{NO}_{3}-\mathrm{N}: \quad 45$, $\mathrm{NH}_{4}-\mathrm{N}: 70, \mathrm{PO}_{4}-\mathrm{P}: 30$ Hernández et al. [18] Sandoval-Heraz o et al. [102] 
University

Nepal

Portugal

Spain

Sri Lanka

Taiwan

Thailand

Turkey

USA

Municipal

Tannery

Domestic

Municipal

Municipal

Domestic

Domestic

Seafood

Domestic

Fermented fish production

Collection

Domestic

Municipal

Domestic
Community system for

business and hotel

Nursery

Domestic

Tilapia

production

Stormwater runoff plant

Canna indica mixed with other Canna flaccida, Zantedeschia aethiopica, Canna indica, Agapanthus africanus and Watsonia borbonica

Canna indica

Canna indica

Strelitzia reginae

Iris $\mathrm{sp}$

Iris pseudacorus

Canna iridiflora

Canna sp

Canna siamensis, Heliconia spp and Hymenocallis littoralis

Heliconia psittacorum L.f. and Canna generalis L. Bailey

Canna hybrida

Cannae lilies, Heliconia

asiaticum, Spathiphyllum clevelandii Schott Iris australis

Canna flaccida, Gladiolus sp., Iris $\mathrm{sp}$.

Canna. generalis, Eleocharis dulcis, Iris Peltandravirginica.

Iris pseudacorus L., Canna $x$. generalis L.H. Bail., Hemerocallis fulva L. and Hibiscus moscheutosL..

Canna sp.

Canna $x$ generalis Bailey, Iris pseudacorus L., Zantedeschia aethiopica (L.)
TSS: 97, COD: 97, BOD: 89 , TP: $>30$

COD: 41-73, BOD: 41-58

BOD, COD, $\mathrm{P}_{-} \mathrm{PO}_{4}, \quad \mathrm{NH}_{4}$ and total coliform bacteria (all up to 84 ) Bacteria: 37

Bacteria: 43

BOD:66, TP:

89, $\quad \mathrm{NH}_{4}-\mathrm{N}: 82, \quad$ [108]

$\mathrm{N}-\mathrm{NO}_{3}: 50$

N-NH4: 73, BOD: 11

N-NH4: 57,

$\mathrm{N}-\mathrm{NO}_{3}: 57$

COD: $\quad 92$, BOD: 93, TSS: 84, NH4-N: 88, TP: 90

BOD: 91-99, SS: 52-90, TN: 72-92 and TP: $72-77$

TSS: Both $>88$, COD: $42-83$

BOD, COD, TKN: 97

BOD: 92, TSS: 90, NO3-N: 50, TP: 46

$$
\text { PO4-P: 20 }
$$

$\mathrm{NH}_{4}-\mathrm{N}: \quad 91$, $\mathrm{NO}_{3}-\mathrm{N}: 89, \mathrm{TN}: 91$

Baceria: $\sim 50$

$\mathrm{N}: \sim 50, \mathrm{P}: \sim 60$

BOD $>75$,

TSS $>88, \quad$ Fecal baceteria $>93$

TSS: $\quad 90$

$\mathrm{NO}_{2}-\mathrm{N}: 91, \mathrm{NO}_{3}-\mathrm{N}$ :

76, COD: 12.5 and

$\mathrm{NH}_{3}-\mathrm{N}: 7.5$

$$
\begin{aligned}
& \mathrm{N} \text { and } \mathrm{P} \\
& \text { Canna }(>90),
\end{aligned}
$$$$
\text { Iris (>30) }
$$

Zantedeschia
Martínez et al.

[21]

Sigh et al. [103]

Calheiros et al.

[104]

Calheiros et al.

[105]

García et al.
[106]

Ansola et al. [107]

Weragoda et al.

$$
\begin{aligned}
& \text { Chyan et al. } \\
& \text { [109] Chyan et al. } \\
& {[110]^{* * *}} \\
& \text { Sirianuntapiboo }
\end{aligned}
$$
$\mathrm{n}$ and Jitvimolnimit [111]

Sohsalam et al. [112]

Konnerup et al. [113]

Kantawanichkul et al. [114]

Brix et al. [115]

Torit et al. [116]

Tunçsiper [117]

Neralla et al. [118]

Palomsky et al. [119]

Karathanasis et al. [14]

Zachritz et al. [120]

Chen et al. [121] 


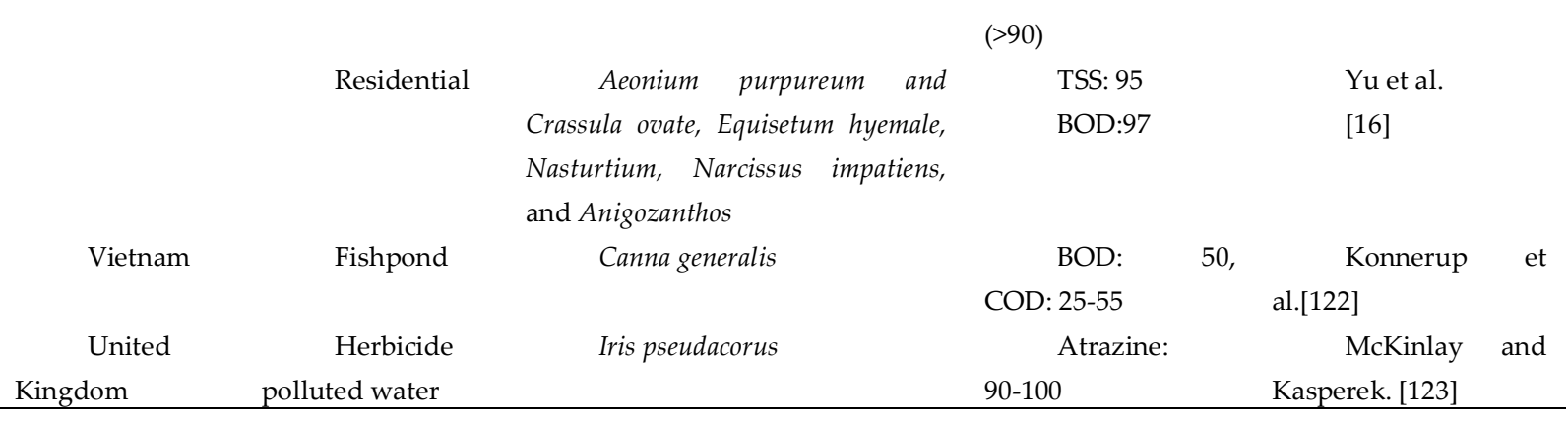

A review of the available literature showed that ornamental plants are used to remove pollutants from domestic, municipal, aquaculture ponds, industrial or farm wastewater. The removal efficiency of ornamental plants was also evaluated for the following parameters: biochemical oxygen demand (BOD), chemical oxygen demand (COD), total suspended solids (TSS), total nitrogen $(\mathrm{TN})$, total phosphorous $(\mathrm{TP})$, ammonium $\left(\mathrm{NH}_{4}-\mathrm{N}\right)$, nitrates $\left(\mathrm{NO}_{3}-\mathrm{N}\right)$, coliforms and some metals $(\mathrm{Cu}, \mathrm{Zn}, \mathrm{Ni}$ and $\mathrm{Al})$. There is no clear pattern in the use of certain species of ornamental plants for certain types of wastewater. However, it is important to keep in mind that CWs using ornamental plants are usually utilized as secondary or tertiary treatments, due to the reported toxic effects that high organic/inorganic loading has on plants in systems that use them for primary treatment (in the absence of other complementary treatment options) [27, 28]. The use of OFP in CWs generates an esthetic appearance in the systems. In CWs with high plant production, OFP harvesting can be an economic entity for CW operators, providing social and economic benefits, such as the improvement of system landscapes and a better habitat quality. Some authors have reported that

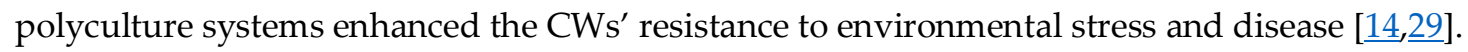

\subsection{Common ornamental plants used in CWs}

A limited quantity of OFP have been used in CWs. These types of plants are typical of subtropical and tropical regions. Our survey showed that the four most frequently used genera are, in order of most to least frequently used: Canna spp, Iris spp, Heliconia spp, Zantedeschia spp (Table 2). Species of the Canna genus are used in all continents, with Asia using them the most frequently. The Iris genus is also used in Asia, along with Europe and North America. Species of the Heliconia genus are commonly used in Asia and America, including Mexico, Central and South America. While Zantedeschia is most frequently used in Mexico (a country in North America), they are found with less frequency in Europe, Africa, and Central and South America. The use of OFP in CWs is most popular in tropical and subtropical regions, due to the warm temperatures and the extensive sunlight hours. Such environmental features stimulate a richer biodiversity than in other regions.

Tabla 2. Four most commonly genera plants used in $\mathrm{CW}$ as identified during the survey according the continents.

\begin{tabular}{|c|c|c|c|c|c|c|c|}
\hline & \multirow[t]{3}{*}{ Asia } & \multirow[t]{3}{*}{ Europe } & \multicolumn{3}{|c|}{ America } & \multirow[t]{3}{*}{ Africa } & \multirow[t]{3}{*}{ Total } \\
\hline & & & \multicolumn{2}{|c|}{ North America } & \multirow{2}{*}{$\begin{array}{l}\text { Central and } \\
\text { South } \\
\text { America }\end{array}$} & & \\
\hline & & & USA & Mexico & & & \\
\hline Canna & 22 & 4 & 5 & 4 & 2 & 2 & 39 \\
\hline Iris & 5 & 5 & 4 & 2 & 2 & & 18 \\
\hline Heliconia & 4 & & & 4 & 4 & & 12 \\
\hline Zantedeschi & & 2 & 1 & 13 & 3 & 1 & 20 \\
\hline
\end{tabular}


151

152

153

154

155

156

157

158

159

160

161

162

163

164

165

166

167

168

169

170

171

This perennial herb belongs to the family Cannaceae (Figure 1). It can grow in full sun or semi-shaded areas and in loamy soils, with plant heights varying from 0.75 to $3.0 \mathrm{~m}$ under tropical and subtropical conditions. It reportedly originated in Central and South America and spread throughout Europe, North America and many tropical regions of the world. The Canna genus includes 8-10 wild species and over 1000 hybrids that are used as garden ornamentals. During the last two centuries of cultivation and improvement, Canna has been transformed into an attractive OFP, with variability in flower colours (yellow, orange, red and salmon, achieved using colored stains) and other positive attributes $[\underline{30}, \underline{31}]$.

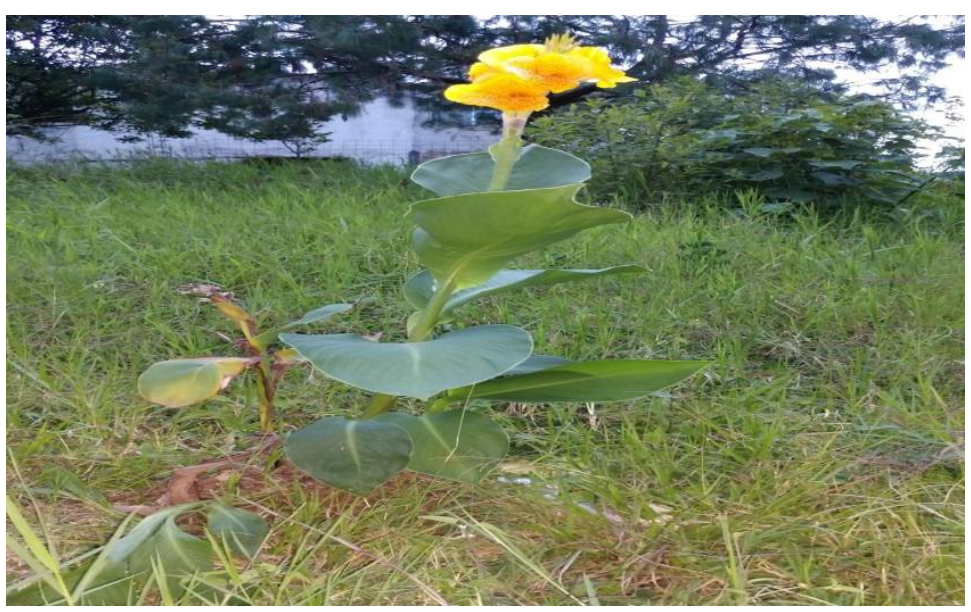

Figure 1.Canna spp

\subsubsection{Iris $\mathrm{spp}$}

Irises are perennial plants (Figure 2), whose flowers are distinguished by a great variety of colours and miscellany of patterns on the perianth leaves [32]. Depending on the species, flower width ranges from 2.5 to $25 \mathrm{~cm}$. Iris leaves are grass-like or sword-like and embrace the shoot with their bracts. Plant height is highly diverse, ranging from 10 to $200 \mathrm{~cm}$, which allows them to be used in a variety of flower compositions. As both the leaves and the flowers are decorative, with the proper selection of species and varieties, they can add splendour to any garden from early spring until late autumn. Irises of the beardless variety (Limniris) are growing in popularity throughout the world, characterized by the various shapes of their perianth sepals and their untypical leafy pistils. They are low-maintenance plants and are resistant to the diseases that affect bearded irises [르, $\underline{3}]$.

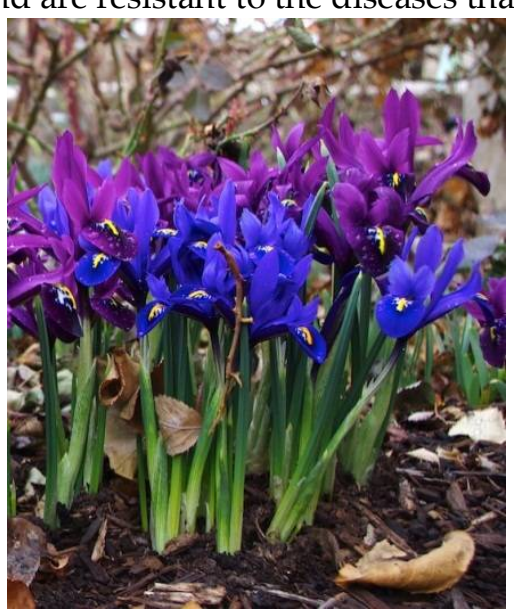

Figure 2.Iris spp 
This species is the only genus in the plant family Heliconiaceae (Figure 3), which is a member of the order Zingiberales. In addition to the several cellular features (short root hair cells, sieve tube plastids with starch, silica bodies, inaperturate and exineless pollen) that distinguish the Zingiberales from other monocots, there are several very conspicuous characters by which they can be recognized, including, 1) large leaves with long petioles and blades possessing transverse venation, 2) large, usually colorful, bracteate inflorescences, and 3) arillate seeds. This order is most closely related to the family Bromeliaceae and their relatives in the superorder Bromeliiflorae [34]. The inverted flowers, presence of a single staminode, and drupaceous fruits are special features of Heliconia. Many species and varieties native from Brazil are now being grown as potted plants and as cut-flowers. The number of species of Heliconia ranges from 120 to over 400 [35] .

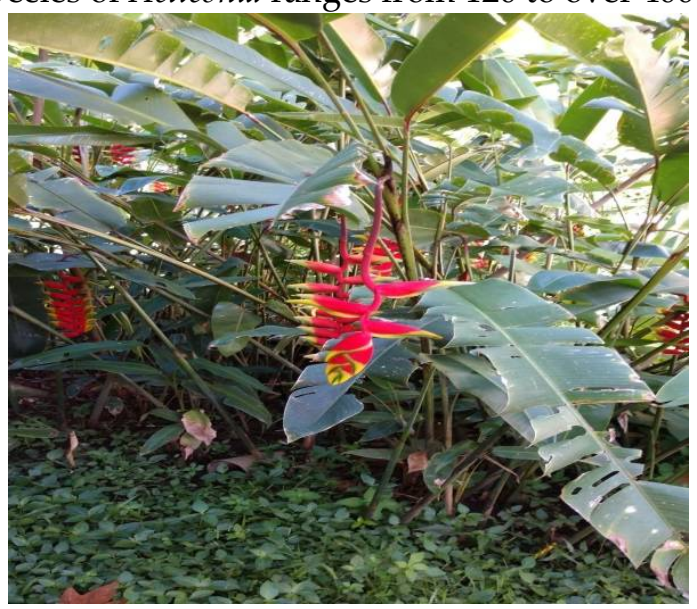

Figure 3.Heliconia spp

\subsubsection{Zantedeschia spp}

Also known as Arum or Calla lilies, a relatively small genus of eight species, forms the tribe Zantedeschieae(Figure 4) in the subfamily Philodendroideae [36]. This genus is confined to southern Africa, including Angola, Zambia, Malawi, Zimbabwe and Tanzania. Showy and decorative hybrids and varieties of Zantedeschia have drawn much interest among plant breeders abroad, where tubers, cut flowers and container plants form the basis of a lucrative export industry in the USA, the Netherlands and New Zealand [36, $\underline{37}]$.

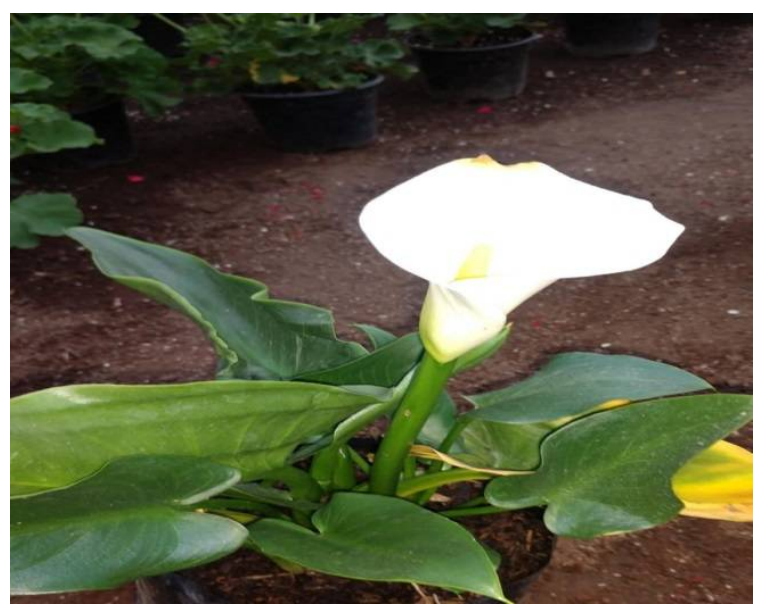

Figure 4.Zantedeschia spp

\subsection{Influence of plants on treatment performance in constructed wetlands}

Some studies have provided evidence of the positive effects that vegetation of natural wetlands has on pollutant removal (organic matter, nitrogen and phosphorus compounds) in constructed 
wetlands when compared to systems without plants $[\underline{5}, \underline{10}]$. In planted mesocosms with Phragmites australis, the efficiency of total nitrogen and total phosphorous removal was $97 \%$ and $91 \%$, respectively, while in systems without plants, the removal efficiency was 53\% for total nitrogen and $61 \%$ for total phosphorous [38]. A similar situation was observed when studying fluoride ion removal in constructed wetlands, where the pollutant removal in systems without plants was $20 \%$ lower than in systems with vegetation [39]. The increase in the removal of pollutants in systems with plants is due to the increased oxygen supply to the rhizosphere through the plants' roots $[2,8]$.

The use of ornamental plants in constructed wetlands for pollutant removal have been applied in different countries around the globe (Table 1), commonly in tropical and subtropical areas. A comparison of performance efficiencies of CWs with different OFP showed that the removal percentages were similar across all plant genera for TSS (62-86\%), COD (41-72\%), BOD (51-82\%), TP $(49-66 \%), \mathrm{NH}_{4}-\mathrm{N}(62-82 \%), \mathrm{NO}_{3}-\mathrm{N}(63-93 \%)$ and $\mathrm{TN}(48-72 \%)$ (Figure5). Such values are within the range reported for [] for CWs from China, India, Ireland, Spain and Thailand, as well as for the values reported in a review of wastewater treatment of CWs in developing countries [푸] and CWs in tropical and subtropical regions [41, $\underline{42}]$, all using plants typically found in natural wetlands (Cyperus, Typha and Phragmites sp.), which were $67-92.5 \%$ for TSS, $49-81 \%$ for COD, $60-91.5 \%$ for BOD, 33-90\% for $\mathrm{NH}_{4}-\mathrm{N}$, and 50-77\% for TP. In general, the mean TN and TP removal when using ornamental plants in CWs were less than the mean removal of the other pollutants (TSS, CDO, BOD, $\mathrm{NH}_{4}-\mathrm{N}$ or $\mathrm{NO}_{3}-\mathrm{N}$ ) (Figure 5). Such removal is influenced not only by the plants, but also by other parameters, such as filter media, or operational parameters, such as hydraulic and influent loading, which are related with the removal of pollutants in CWs and need to be considered in system designs [43]. When comparing the removal efficiency of pollutants in CWs with OFP and CWs without plants (Figure5), pollutant removal was almost $40 \%$ higher for TSS, COD, BOD, NT AND ${\mathrm{N}-\mathrm{NO}_{3}}_{3}$ in $\mathrm{CWs}$ with plants than in those without. For TP the removal efficiency was almost $70 \%$ higher in CWs using ornamental plants than in those without vegetation.

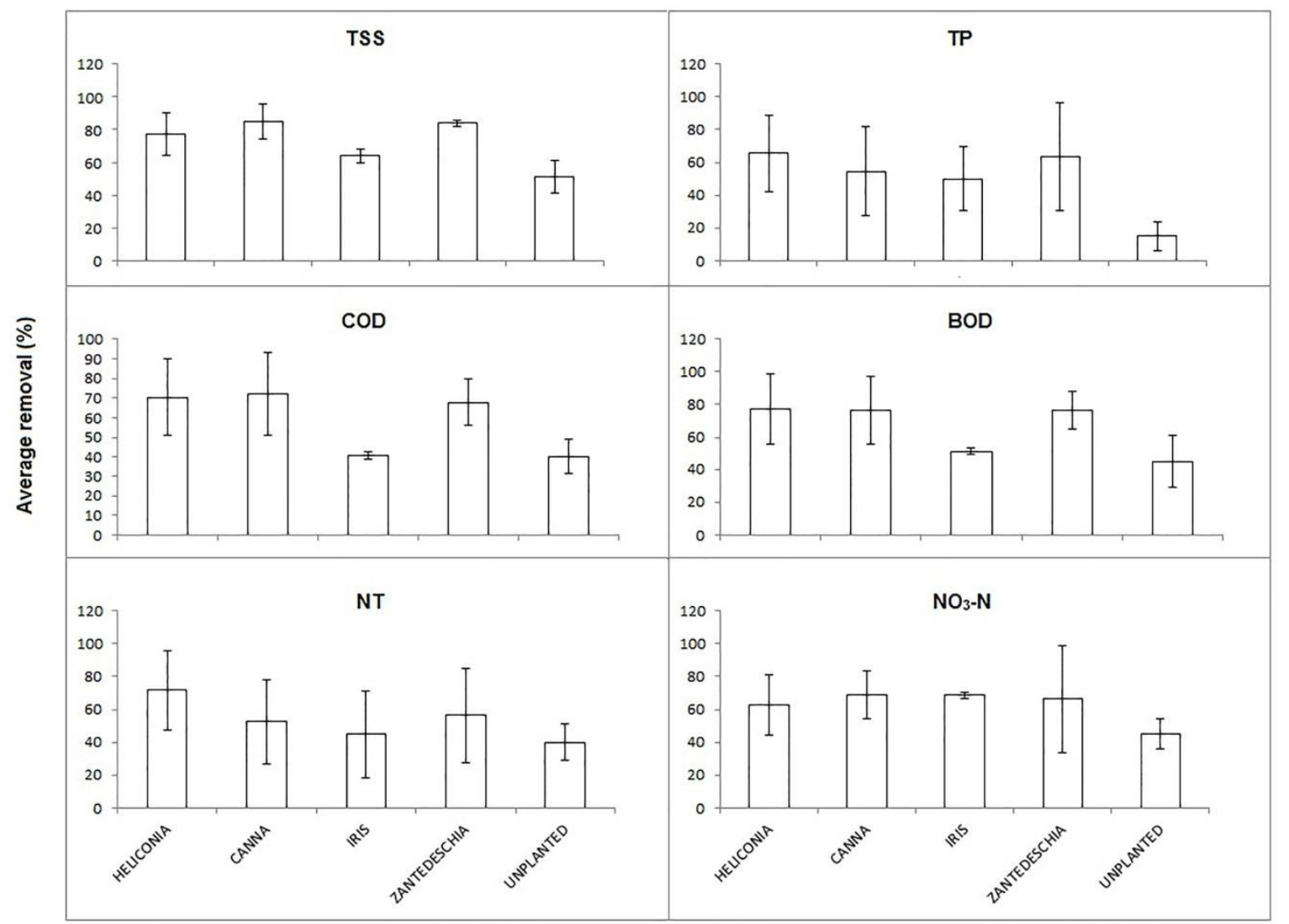

Figure5. Comparing the average removal efficiencies of contaminants using ornamental plants and systems unplanted in various CWs systems in the globe 
Miller et al. [42] evaluated the use of CWs in Brazil, including systems with ornamental plants, and concluded that warm temperatures, extensive sunlight hours and available land are important characteristics for encouraging plant growth and proliferation. Such features are typical in tropical and subtropical regions, where the option of a CW with ornamental plants can be an excellent choice for the removal of pollutants.

In cases where the wetlands are constructed to assist rural communities that involve big areas, the growth of OFP also creates a useful source of commercialization. The flowers could be sold as bouquets, as plants with attached roots for use in gardens, or for crafts made with parts of the plants, providing another strategy for convincing landowners to adopt these systems. The statistics that we report here regarding the removal efficiency of ornamental plants in CWs around the world is evidence that urban areas can also use CW systems as beautiful landscapes in supermarkets, streets, universities, hospitals, in riverine areas or as floating wetlands in rivers, lakes or lagoons. The combination of different species of ornamental plants in CWs makes the system more colorful, and therefore, more attractive for the public.

These comparisons indicate the same general range of removal efficiency between CWs using ornamental plants and CWs with vegetation from natural wetlands. Thus, it is clear that ornamental plants should be considered in new CW designs. The use of ornamental plants could be a strategy used to increase the adoption of these systems because it makes the systems more aesthetic, and therefore, they would not be observed as a treatment system, but instead would be seen as large outdoor planters' in house gardens. We recommend the construction of domiciliary wetlands using ornamental plants to decrease water pollution and to assist with maintaining a better public health.

\subsection{Advantages of using ornamental plants in CWs}

A range of novel and cost-effective constructed wetland systems for wastewater treatment have been engineered around the world. The influence of design parameters, such as porous media, hydraulic retention time, and flow of water, on the performance of CWs has been reported, highlighting the sustainability of this technology and the esthetic appearance using OFP $[\underline{6}, \underline{28}, \underline{43}, \underline{44}]$.

One of the advantages of using OFP in CWs is the significant reduction of nutrient contamination (Figure. 1), representing an economical and sustainable alternative to decentralization practices; CWs are less expensive than commercial systems and are easier to build and operate $[\underline{45}, \underline{46}]$. Furthermore, by using plants with commercial value, the resources invested in the design, construction and maintenance of the system can be recovered in the profits of retail sales, without impeding the removal of pollutants of the system. The production of flowers in the CWs can provide economic benefits to the operators of the technology and can create beautiful landscapes using flowers such as Canna, Iris, Heliconias and Zantedeschia spp. (Tables 1 and 2).

\section{Conclusions}

The use of ornamental flowering plants in constructed wetlands has been identified in 21 countries. The most commonly used ornamental plants are Canna spp., Iris spp, Heliconia spp., and Zantedeschia spp., which are mainly used in tropical and subtropical regions. These plants have been evaluated for the efficiency of pollutant removal in CWs, with studies concluding that they can be used for such a purpose. Our survey also found that many ornamental plants are planted using a mixture of various species, or are mixed with plants from natural wetlands. There is no clear pattern in the use of a specific plant species for a certain type of wastewater, but the use of ornamental plants in wastewater treatment is a great economic and ecological option, and their flowers add to the 
esthetic appearance of CWs. The last characteristic could be used to increase system adoptions by the people in domiciliary, rural or urban areas.

Author Contributions: J.L.M-M. andL.C.S-H. wrote, coordinated and reviewed the paper and finalized the data collection. M.G.H-O and A.J.A-C.contributed to refining the paper structure and to improving the scientific aspects.

Acknowledgments:This work was supported by the El Colegio de Veracruz with the agreement 2017-III-IerExt-21.

Conflicts of Interest:The authors declare no conflict of interest.

\section{References}

1. Kadlec, R.; Wallace, S. Treatment Wetlands2009, Boca Raton, Florida: Taylor and Francis Group.(2nd ed.)

2. Mitsch, WJ.; Gosselink, JG.. Wetlands. Hoboken, NJ: Wiley.2015, (5th ed.)

3. Marín-Muñiz, J.L. Humedales: riñones del planeta y hábitat de múltiples especies. SEV-COLVER.2018, 100p.

4. Brix, H. Functions of macrophytes in constructed wetlands. Water Sci Techn. 1994, 4: 71-78; DOI: https://doi.org/10.2166/wst.1994.0160

5. Shelef, O.; Gross, A.; Rachmilevitch, S. Role of plants in a constructed wetland: Current and new perspectives. Water. 2013, 5, 405-419; DOI: 10.3390/w5020405

6. Valipour, A.; Ahn, Y. Constructed wetlands as sustainable ecotechnologies in decentralization practices: a review. Environ PollutRes. 2016,23, 180-197; DOI: https://doi.org/10.1007/s11356-015-5713-y

7. Valipour, A.; Azizi, S.; Raman, VK.; Jamshidi, S.; Hamnabard, N.The comparative evaluation of the performance of two phytoremediation systems for domestic wastewater treatment. Environ Sci Eng.2014, 56, 319-326; Available online: https://europepmc.org/abstract/med/26563084.( accessed on 30/ august 2018).

8. Vymazal, J. Plants used in constructed wetlands with horizontal subsurface flow: a review. Hydrobiologia.2011,20, 133-156; DOI: https://doi.org/10.1007/s10750-011-0738-9

9. Vymazal, J. Emergent plant used in free water surface constructed wetlands: A review. Ecol. Eng.61, 582-592; DOI: https://doi.org/10.1016/j.ecoleng.2013.06.023.

10. Wang, C.; Zhang, M.; Ye, M.; Wang, J.; Li, G. Pilot-scale electrochemical oxidation combined with constructed wetland system for unconventional surface water treatment. J Chem Technol Biotechnol.2014,89, 1599-1606; DOI: https://doi.org/10.1002/jctb.4464.

11. Mburu, N.; Rousseau, D.; Bruggen, J.; and Lens, P. Use of macrophyte Cyperus papyrus in wastewater treatment. Springer International Publishing Switzerland.2015, DOI: https://doi.org/10.1007/978-3-319-08177-9 20.

12. Bachand, PAM.; Horne, AJ. Denitrification in constructed free-water surfacewetland: II. Effects of vegetation and temperature.Ecol Eng.2000,14, 17-32; DOI: https://doi.org/10.1016/S0925-8574(99)00017-8.

13. Tilley, DR.; Badrinarayanan, H.; Rosati, R.; Son, J. Constructed wetlandsas recirculation filters in large-scale shrimp aquaculture. Aquacult Eng.2002, 26, 81-109; DOI: https://doi.org/10.1016/S0144-8609(02)00010-9.

14. Karathanasis, AD.; Potter, CL.; Coyne, MS. Vegetation effects on fecal bacteria, BOD, and suspended solid removal in constructed wetlands treating domestic wastewater. Ecol Eng.2003, 20, 157-169; DOI: https://doi.org/10.1016/S0925-8574(03)00011-9.

15. Chang, NB.; Islam, K.; Marimon, Z.; Wanielista, MP. Assessing biological and chemical signatures related to nutrient removal by floating islands in stormwater mesocosms. Chemosphere. 2012,88(6), 736-743; DOI: https://doi.org/10.1016/j.chemosphere.2012.04.030.

16. Yu, Z.; Bill, B.; Stenstrom, M.; Cohen, Y. Feasibility of a semi-batch vertical-flow wetland for onsite residential gray water treatment. Ecol. Eng.2015, 82, 311-322; DOI: https://doi.org/10.1016/j.ecoleng.2015.04.087.

17. Wang, Q.; Hu, Y.; Xie, H.; Yang, Z. Constructed wetlands: A review on the role of radial oxygen loss in the rhizosphere by macrophytes. Water.2018, 10, 678; DOI: https://doi.org/10.3390/w10060678. 
18. Hernández, ME.; Galindo-Zetina, M.; Hernandez-Hernández JC. Greenhouse gas emissions and pollutant removal in treatment wetlands with ornamental plants under subtropical conditions.Ecological Engineering.2018, 114: 88-95; DOI: https://doi.org/10.1016/j.ecoleng.2017.06.001.

19. Lai. W.; Zhang, Y.; Chen, Z. Radial oxygen loss, photosynthesis, and nutrient removal of 35 wetland plants.Ecological Engineering.2012, 39: 24-30; DOI: https://doi.org/10.1016/j.ecoleng.2011.11.010.

20. Martínez, N.; Tejeda, A.; Del Toro, A., Sánchez, Zurita, F. Nitrogen removal in pilot-scale partially saturated vertical wetlands with and without and internal source of carbon. Sci. Total Environt.2018,645: 524-532; DOI: https://doi.org/10.1016/j.scitotenv.2018.07.147.

21. Braskerud, B.C. The influence of vegetation on sedimentation and resuspension of soil particles in small constructed wetlands.J.l Environ. Qual. 2001, 30: 1447-1457; DOI: 10.2134/jeq2001.3041447x.

22. Baptestini G.; Matos, A.; Martinez, M.; Borges, A.; Matos M.Hydraulic conductivity variability in horizontal subsurface flow constructed wetlands. J. Braz. Assoc. Agri. Eng. 2017, 37(2): 333-342; DOI: http://dx.doi.org/10.1590/1809-4430-eng.agric.v37n2p333-342/2017

23. Stottmeister, U.; Wiebner, A.; Kuschk, P.; Kappelmer, U.; Kästner, M.; Bederski, O.; Müler, RA.; Moormann, H. Effects of plants and microotganisms in constructed wetlands for wastewater treatment. Biotecnol. Adv.2003, 22, 93-117; DOI: https://doi.org/10.1016/j.biotechadv.2003.08.010.

24. Tanner, CC. Plants for constructed wetland treatment systems-a comparison of the growth and nutrient uptake of eigh emergent species. Ecol Eng.1996, 7, 59-83; DOI: https://doi.org/10.1016/0925-8574(95)00066-6.

25. Liu, X.; Huang, S.; Tang, T.; Liu, X.; Scholz, M. Growth characteristic and nutrient removal capability of plants in subsurface vertical flow constructed wetlands. Ecol. Eng. 2012, 44, 189-198; DOI: https://doi.org/10.1016/j.ecoleng.2012.03.011.

26. Paulo, PL.; Begosso, L.; Pansonato, N.; Shrestha, RR.; Bonez, MA. Design and configuration criteria for wetland systems treating greywater. Water Sci Technol 2009, 60(8), 2001-2007; DOI: https://doi.org/10.2166/wst.2009.542.

27. Paulo, PL.; Azevedo, C.; Begosso, L.; Galbiati, AF.;Boncz, MA. Natural systems treating greywater and blackwater on-site: integrating treatment, reuse and landscaping. Ecol Eng.2013, 50, 95-100; DOI: https://doi.org/10.1016/j.ecoleng.2012.03.022.

28. Sarmento, AP.; Borges, AC.; Matos AT. Effect of cultivated species and retention time on the performance of constructed wetlands.Environ Technol. 2013, 35 (8), 961-965; DOI: https://doi.org/10.1080/09593330.2012.724210.

29. Prata, R.; Matos, A.; Cecon, P.; Monaco, P.; Pimenta, L. Sewage treatment in wetlands cultivated with yellow lilly. Eng. Agrícola.2013, 33, 1144-1155; DOI: http://dx.doi.org/10.1590/S0100-69162013000600007(In Portuguese).

30. Teodoro, A.; Boncz, M.; Júnior, A.; Paulo, P. Disinfection of greywater pretreated by constructed wetlands using photo-Fenton: influence of $\mathrm{pH}$ on the decay of Pseudomonas aeruginosa. J. Environ. Chem. Eng. 2014, 2, 958-962; DOI: http://dx.doi.org/10.1016/j.jece.2014.03.013

31. Shi, L.; Wang, BZ.; Cao, XD.; Wang, J.; Lei, ZH.; Wang, ZR.; Liu, ZY.; Lu, BN. Performance of a subsurface-flow constructed wetland in Southern China. J Environ Sci. 2004, 16(3), 476-481; Avaibable online: https://content.iospress.com/articles/journal-of-environmental-sciences/jes16-3-27. ( accessed on 30 July 2018).

32. Li, G.; Wu, Z.; Cheng, S.; Liang, W.; He, F.; Fu, G.; Zhong, F. Application of constructed wetlands on wastewater treatment for aquaculture ponds. Wuhan University J Natur Sci 2007, 12, 1131-1135; DOI: https://doi.org/10.1007/s11859-007-0116-7.

33. Yang, Q.; Chen, Z.; Zhao, J.;Gu, B. Contaminant removal of domestic wastewater by constructed wetlands: Effects of plant species. J Integrat Plant Biol. 2007, 49(4), 437-446; DOI: https://doi.org/10.1111/j.1744-7909.2007.00389.x.

34. Zhang, ZH.; Rengel, Z.; Meney, K. Nutrient removal from simulated wastewater using Canna indica and Schoenoplectus validus in mono- and mixedculture in wetland microcosms?Water Air Soil Pollut.2007, 183(1-4), 95-105; DOI: https://doi.org/10.1007/s11270-007-9359-3.

35. Zhang, XB.; Liu, P.; Yang, YS.; Chen, WR. Phytoremediation of urban wastewater by model wetlands with ornamental hydrophytes.J Environ Sci (China). 2007, 19(8), 902-909; Avaibable online: 
http://www.jesc.ac.cn/jesc_en/ch/reader/create_pdf.aspx?file_no=2007190802\&year_id=2007\&quarter_id=8\&fal $\mathrm{g}=1$. ( accessed on 25 july 2018).

36. Sun, LP.; Liu, Y.; Jin, H. Nitrogen removal from polluted river by enhanced floating bed grown canna. Ecol Eng. 2009, 35(1), 135-140; DOI: https://doi.org/10.1016/j.ecoleng.2008.09.016.

37. Cui, L.; Ouyang, Y.; Lou, Q.; Yang, F.; Chen, Y.; Zhu, W.; Luos, S. Removal of nutrients from wastewater with Canna indica L. under different vertical-flow constructed wetland conditions. Ecol Eng. 2010, 36, 1083-1088; DOI: https://doi.org/10.1016/j.ecoleng.2010.04.026.

38. Zhang, S. ; Zhou, Q. ; Xu, D. ; He, F. ; Cheng, S. ; Liang, W. ; Du, C.; Wu, Z. Vertical-flow constructed wetlands applied in a recirculating aquaculture system for channel catfish culture: Effects on water quality and zooplankton. Polish J Environ Stud. 2010, 19, 1063-1070; Avaibable online: https://www.researchgate.net/profile/Shiyang Zhang2/publication/268002624 Vertical-Flow Constructed Wet lands Applied in a Recirculating Aquaculture System for_Channel Catfish Culture Effects on Water Qu ality and Zooplankton/links/0f31753ab7456f0f79000000.pdf. ( accessed on 30 july 2018).

39. Qiu, Z.; Wang, M.; Lai, W.; He, F.; Chen, Z. Plant growth and nutrient removal in constructed monoculture and mixed wetlands related to stubble attributes. Hydrobiologia. 2011, 661, 251-260; DOI: https://doi.org/10.1007/s10750-010-0530-2

40. Wen, L.; Hua, C.; Ping, Z.; Xiang, L. Removal of total phosphorus from septic tank effluent by the hybrid constructed wetland system. Procedia Environ Sci 2011, 10, 2102-2107; DOI: https://doi.org/10.1016/j.proenv.2011.09.328.

41. Wu, H.; Zhang, J.; Li, P.; Zhang, J.; Xie, H.; Zhang, B. Nutrient removal in constructed microcosm wetlands for treating polluted river water in northern China. Ecol Eng. 2011, 37, 560-568; DOI: https://doi.org/10.1016/j.ecoleng.2010.11.020.

42. Xie, X.; He, F.; Xu, D.; Dong, J.; Cheng, S.; Wu, Z. Application of large scale integrated vertical-flow constructed wetland in Beijing Olympic forest park: design, operation and performance. Water Environ J. 2012, 26,100-107; DOI: https://doi.org/10.1111/j.1747-6593.2011.00268.x

43. Chang, JJ.; Wu, SQ.; Dai, YD.; Liang, W.; Wu, ZB. Treatment performance of integrated vertical-flow constructed wetland plots for domestic wastewater. Ecol Eng. 2012, 44, 152-159; DOI: https://doi.org/10.1016/j.ecoleng.2012.03.019.

44. Gao, J.; Wang, W.; Guo, X.; Zhu, S. Nutrient removal capability and growth characteristics of iris sibrica in subsurface vertical flow constructed wetlands in winter. Ecol Eng. 2014, 70, 351-361; DOI: https://doi.org/10.1016/j.ecoleng.2014.06.006.

45. Li, J.; Liu, X.; Yu, Z.; Yi, X.; Ju, Y.; Huang, J.; Liu, R. Removal of fluoride and arsenic by pilot vertical-flow constructed wetlands using soil and coal cinder as substrate. Water Sci Technol. 2014, 70(4), 620-626; DOI: Available online https://web.a.ebscohost.com/abstract?direct=true\&profile=ehost\&scope=site\&authtype=crawler\&jrnl=02731223 \&AN=97456645\&h=cspE3Yp1FT7Z\%2b0L2W35da\%2fEuUxoalBsN2ZCvbYjk\%2bw\%2fRNmEf4yID97zVeiXT5a IdoP7AUS0QmaxQoiq\%2fTsvtUg\%3d\%3d\&crl=c\&resultNs=AdminWebAuth\&resultLocal=ErrCrlNotAuth\&cr $\underline{\text { lhashurl=login.aspx } \% 3 \text { firect } \% 3 d \text { true } \% 26 \text { profile } \% 3 \text { dehost } \% 26 \text { scope } \% 3 \text { dsite } \% 26 \text { authtype } \% 3 \text { dcrawler } \% 26 j \text { rnl } \%}$ 3d02731223\%26AN\%3d97456645. (accessed on 02 August 2018).

46. Gao, J.; Zhang, J.; Ma, N.; Wang, W.; Ma, C.; Zhang, R. Cadmium removal capability and growth characteristics of iris sibrica in subsurface vertical flow constructed wetlands. Ecol Eng. 2015, 84, 443-450; DOI: https://doi.org/10.1016/j.ecoleng.2015.07.024.

47. Hu, Y.; He, F.; Ma, L.; Zhang, Y.; Wu, Z. Microbial nitrogen removal patways in integrated vertical-flow constructed wetland systems. Bioresou Technol. 2016, 207, 339-345; DOI: https://doi.org/10.1016/j.biortech.2016.01.106.

48. Wang, W.; Ding, Y.; Ullman, J.; Ambrose, R.; Wang, Y.; Song, X.; Zhao, Z. Nitrogen removal performance in planted and unplanted horizontal subsurface flow constructed wetlands treating different influent COD/N ratios. Environ Sci Pollut Res. 2016, 23, 9012-9018; DOI: https://doi.org/10.1007/s11356-016-6115-5.

49. Morales, G.; López, D.; Vera, I.; Vidal, G. Humedales construidos con plantas ornamentales para el tratamiento de materia orgánica y nutrientes contenidos en aguas servidas. Theoria.2013, 22(1), 33-46; Available Online: http://revistas.ubiobio.cl/index.php/RT/article/view/1188. 
50. Burgos, V.; Araya, F.; Reyes-Contreras, C.; Vera, I.; Vidal, G. Performance of ornamental plants in mesocosm subsurface constructed wetlands under different organic sewage loading constructed wetlands under different organic sewage loading. Ecol Eng. 2017, 99, 246-255; DOI: https://doi.org/10.1016/j.ecoleng.2016.11.058.

51. Leiva A.; Núñez R.; Gómez G.; López D.; Vidal G. Performance of ornamental plants in monoculture and polyculture horizontal subsurface flow constructed wetlands for treating wastewater. Ecol. Eng.2018, 120: 116-125; DOI: https://doi.org/10.1016/j.ecoleng.2018.05.023.

52. Gutiérrez-Mosquera, H.; Peña-Varón, M. Eliminación de nitrógeno en un humedal construido subsuperficial, plantado con Heliconia psíttacorum. Tecnología Ciencias del agua. 2011,11(3), 49-60; Available online: http://www.scielo.org.mx/scielo.php?pid=S2007-24222011000300004\&script=sci arttext. (accessed on 13 August 2018)

53. Madera-Parra, CA.; Peña-Salamanca, EJ.; Peña, MR.; Rousseau, DPL.; Lens PN. Phytoremediation of landfill leachate with Colocasia esculenta, Gynerum sagittatum and Heliconia psittacorum in Constructed Wetlands.Int J Phytoreme. 2015, 17, 16-24; DOI: https://doi.org/10.1080/15226514.2013.828014.

54. Marrugo-Negrete, J.; Ortega-Ruíz, J.; Navarro-Frómeta, A.; Enamorado-Montes, G.; Urango-Cárdenas, I.; Pinedo-Hernández, J.; Durango-Hernández, J.; Estrada-Martínez, A. Remoción de cipermetrina presente en el baño de ganado utilizando humedales construidos. Corpoica Cienc Tecnol Agrop.2016, 17(2), 203-216.

55. Toro-Vélez, AF.; Madera-Parra, CA.; Peñón-Varón, MR.; Lee, WY.; Bezares-Cruz, JC.; Walker, WS.; Cárdenas-Henao, H.; Quesada-Calderón, S.; García-Hernández, H.; Lens, PNI. BPA and NP removal from municipal wastewater by tropical horizontal subsurface constructed wetlands.Sci Total Environ. 2016, 542, 93-101.

56. León, C.; Cháves, D. Tratamiento de residual vacuno utilizando microalgas, la lenteja de agua Lemna aequinoctiales y un humedal subsuperficial en Costa Rica. Rev Latinoam Biotecn Amb Alga. 2010, 1(2), 155-177; DOI: https://doi.org/10.1016/j.scitotenv.2015.09.154.

57. Abou-Elela, S.; Hellal, M. Municipal wastewater treatment using vertical flow constructed wetlands planted with Canna, Phragmites and Cyprus. Ecol Eng. 2012, 47, 209-213; Available online: http://www.solabiaa.org/ojs3/index.php/RELBAA/article/view/22. (accessed on 13 August 2018)

58. Abou-Elela, S.; Golinielli, G.; Abou-Taleb, E.; Hellal, M. Municipal wastewater treatment in horizontal and vertical flows constructed wetlands. Ecol Eng. 2013, 61, 460-468; DOI: https://doi.org/10.1016/j.ecoleng.2013.10.010.

59. Choudhary, AK.; Kumar, S.; Sharma, C. Removal of chlorinated resin and fatty acids from paper mill wastewater through constructed wetland. World Acad Sci Eng Technol. 2010, 80, 67-71; Available online: https://pdfs.semanticscholar.org/5c68/29075154522d7f2486c7f96ed897d796b2b6.pdf.(accessed on 08 August 2018).

60. Yadav, A.; Dash, P.; Mohanty, A.; Abbassi, R.; Mishra, B. Performance assessment of innovative constructed wetland-microbial fuel cell for electricity production and dye removal. Ecol Eng. 2012, 47, 126-131; DOI: https://doi.org/10.1016/j.ecoleng.2012.06.029

61. Saumya, S.; Akansha, A.; Rinaldo, J.; Jayasri, MA.; Suthindhiran, K. Construction and evaluation of prototype subsurface flow wetland planted with Heliconia angusta for the treatment of synthetic greywater. $J$ Cleaner Product.2015, 91, 235-240; DOI: https://doi.org/10.1016/j.jclepro.2014.12.019.

62. Ojoawo, S.; Udayakuman, G.; Naik, P. Phytoremediation of phosphorus and nitrogen with Canna $x$ generalis reeds in domestic wastewater through NMAMIT constructed wetlands. Aquatic procedia.2015, 4, 349-356; DOI: https://doi.org/10.1016/j.aqpro.2015.02.047.

63. Haritash, AK.; Sharma, A.; Bahel, K. The potential of Canna lily for wastewater treatment under Indian conditions.Int J Phytoremed. 2015, 17(10), 999-1004; DOI: https://doi.org/10.1080/15226514.2014.1003790.

64. Patil, YM.;Munavalli, GR. Performance evaluation of and integrated on-site greywater treatment systm in a tropical region. Ecol Eng. 2016, 95, 492-500; DOI: https://doi.org/10.1016/j.ecoleng.2016.06.078

65. Singh, M.; Srivastava, R. Horizontal subsurface flow constructed wetland for heavy metal removal from domestic wastewater. Environ Progress Sustain Energy. 2016, 35(1), 125-132; DOI: https://doi.org/10.1002/ep.12214. 
66. Gill, LW.; O'Luanaigh, N. Nutrient removal from on-site wastewater in horizontal subsurface flow constructed wetlands in Ireland. Water Pract Techn. 2011, 6(3), 1-2; DOI: https://doi.org/10.1016/j.ecoleng.2010.06.002.

67. Macci, C.; Peruzzi, E.; Doni, S.; Iannelli, R.; Masciandaro, G. Ornamental plants for micropollutant removal in wetland systems. Environ Sci Pollut Res. 2015, 22, 2406-2415; DOI: https://doi.org/10.1007/s11356-014-2949-x.

68. Kimani, RW.; Mwangi, BM.; Gichuki, CM. Treatment of flower farm wastewater effluents using constructed wetlands in lake Naivasha Kenya. Indian J Sci Technol. 2012, 5, 1870-1878; Avalidable Online: http://repository.embuni.ac.ke/handle/123456789/80. (accessed on 08 December 2018)

69. Belmont, MA.; Metcalfe, CD. Feasibility of using ornamental plants (Zantedeschia aethiopica) in subsurface flow treatment wetlands to remove nitrogen, chemical oxygen demand and nonylphenol ethoxylate surfactants - a laboratory-scale study.Ecol Eng. 2003, 21, 233-247; DOI: https://doi.org/10.1016/j.ecoleng.2003.10.003.

70. Belmont, MA.; Cantellano, E.; Thompson, S.; Williamson, M.; Sánchez, A.; Metcalfe, CD. Treatment of domestic wastewater in a pilot scale natural treatment system in central Mexico. Ecol Eng. 2004, 23, 299-311; DOI: https://doi.org/10.1016/j.ecoleng.2004.11.003.

71. Orozco, C.; Cruz, A.; Rodríguez, M.; Pohlan, A. Humedal subsuperficial de flujo vertical como sistema de depuración terciaria en el proceso de beneficiado de café. Hig Sanid Ambient.2006, 6, 190-196; Avaidable Online: http://www.salud-publica.es/secciones/revista/revistaspdf/bc51015a2fc8ef6 Hig.Sanid.Ambient.6.190-196(2006 ..pdf/. (accessed on 13 july 2018).

72. Zurita, F.; De Anda, J.; Belmont, M. Performance of laboratory-scale wetlands planted with tropical ornamental plants to treat domestic wastewater. Water Qual Res J Canada.2006, 41(4), 410-417; DOI: https://doi.org/10.2166/wqrj.2006.044.

73. Zurita, F.; Belmont, M.; De Anda, J.; Cervantes-Martínez, J. Stress detection by laser-induced fluorescence in Zantedeschia aethiopica planted in subsurface-flow treatment wetlands. Ecol Eng. 2008, 33, 110-118; DOI: https://doi.org/10.1016/j.ecoleng.2008.02.004.

74. Ramírez-Carrillo, HF.; Luna-Pabello, VM.; Arredondo-Figueroa, JL. Evaluación de un humedal artificial de flujo vertical intermitente, para obtener agua de buena calidad para la acuicultura. Rev Mex Ing Quím. 2009, 8(1), 93-99; Avaidable Online: http://www.scielo.org.mx/scielo.php?pid=S1665-27382009000100009\&script=sci arttext\&tlng=en. (accessed on 13 August 2018).

75. Zurita, F.; De Anda, J.; Belmont, MA. Treatment of domestic wastewater and production of commercial flowers in vertical and horizontal subsurface-flow constructed wetlands. Ecol Eng. 2009, 35(5), 861-869; DOI: https://doi.org/10.1016/j.ecoleng.2008.12.026.

76. Zurita, F.; Del Toro-Sánchez, C.; Gutierrez-Lomelí, M.; Rodríguez-Sahagún, A.; Castellanos-Hernández, O.; Ramirez-Martínez, G.; White, J. Preliminary study on the potential of arsenic removal by subsurface flow constructed mesocosms. Ecol Eng. 2012, 47, 101-104; DOI: https://doi.org/10.1016/j.ecoleng.2012.06.018.

77. Castañeda, AA.; Flores, HE. Tratamiento de aguas residuales domésticas mediante plantas macrófitas típicas en Los Altos de Jalisco, México. Paakat Rev Tecn Soc. 2013, 3(5), 126-134; Avaidable Online: https://dialnet.unirioja.es/servlet/articulo?codigo=5815442. (accessed on 13 july 2018).

78. Zurita, F.; White, J. Comparative study of three two-stage hybrid ecological wastewater treatment systems for producing high nutrient, reclaimend water for irrigation reuse in developing countries. Water. 2014, 6, 213-228; DOI: $\underline{10.3390 / w 6020213}$

79. Hallack, M.; Payan, JC.; Mungaray, A.; López, A.; González, M.; Castañón, MC.; Pérez-Banuet, M. Implementación y evaluación de un sistema de tratamiento de agua residual natural a través de humedales construidos en el noroeste de México. In Gestión de humedales españoles y Mexicanos: Apuesta conjunta por su futuro. (coord..). Sastre A., Díaz I and Ramíres J. Universidad de Alcalá.2015; I.S.B.N.: 978-84-16599-15-8. Avaidable Online: http://www.redalyc.org/pdf/370/37012012004.pdf . (accessed on 13 november 2018).

80. Méndez-Mendoza, A.; Bello-Mendoza, R.; Herrea-López, D.; Mejía-González, G.; Calixto-Romo, A. Performance of constructed wetlands with ornamental plants in the treatment of domestic wastewater under 
the tropical climate of south Mexico. Water Practice Tecnol. 2015, 10(1), 110-123; DOI: https://doi.org/10.2166/wpt.2015.013

81. Merino-Solís, M.; Villegas, E.; de Anda, J.; López-López, A. The effect of the hydraulic retention time on the performance of an ecological wastewater treatment system: An anaerobic filter with a constructed wetland. Water.2015, 7, 1149-1163; DOI: https://doi.org/10.3390/w7031149

82. Zurita, F.; Carreón-Álvarez, A. Performance of three pilot-scale hybrid constructed wetlands for total coliforms and Escherichia coli removal from primary effluent - a 2-year study in subtropical climate. J Water Health. 2015, 13(2), 446-458; DOI: https://doi.org/10.2166/wh.2014.135

83. Garzón, M.; González, J.;García, R. Evaluación de un sistema de tratamiento doméstico para reúso de agua residual. Rev. Int. Cont. Amb. 2016, 32(2), 199-211; DOI: http://dx.doi.org/10.20937/RICA.2016.32.02.06

84. Hernández, ME. Humedales ornamentales con participación comunitaria para el saneamiento de aguas municipales en México. RINDERESU. 2016, 1(2), 1-12; DOI: Avaidable Online: http://rinderesu.com/index.php/rinderesu/article/view/16. Access ed on 17 September 2018

85. López-Rivera, A.; López-López, A.; Vallejo-Rodríguez, R.; León-Becerril, E. Effect of the organic loading rate in the stillage treatment in a constructed wetland with Canna indica.Environ Progress Sust Energy. 2016, 35(2), 411-415.https://doi.org/10.1002/ep.12249

86. Tejeda, A.; Torres-Bojorges, A.; Zurita, F. Carbamazepine removal in three pilot-scale hybrid wetlands planted with ornamental species. Ecol Eng.2017, 98, 410-417; DOI: https://doi.org/10.1016/j.ecoleng.2016.04.012

87. Marín-Muñiz, J.L.; García-González, M.C.; Ruelas-Monjardín, L.C.; Moreno-Casasola, P. Influence of different porous media and ornamental vegetation on wastewater pollutant removal in vertical subsurface flow wetland microcosms. Environ. Eng. Sci. 2018, 35 (2), 88-94; DOI: https://doi.org/10.1089/ees.2017.0061

88. Sandoval-Herazo, L.C.; Alvarado-Lassman, A.A.; Marín-Muñiz, J.L.; Méndez-Contreras, J.M.; Zamora-Castro, S.A.; Effects of the use of ornamental plants and different substrates in the removal of wastewater pollutants through microcosms of constructed wetlands. Sustainability. 2018, 10, 1594; DOI: https://doi.org/10.3390/su10051594

89. Singh, S.; Haberl, R.; Moog, O.; Shrestha, RR.; Shrestha, P.; Shrestha, R. Performance of an anaerobic baffled reactor and hybrid constructed wetland treating high-strength wastewater in Nepal-a model for DEWATs. Ecol Eng. 2009, 35(5), 654-660; DOI: https://doi.org/10.1016/j.ecoleng.2008.10.019

90. Calheiros, CS.; Rangel, OSS.;Castro, PKL. Constructed wetland systems vegetated with different plants applied to the treatment of tannery wastewater. Water Res. 2007, 41, 1790-1798; DOI: https://doi.org/10.1016/j.watres.2007.01.012

91. Calheiros, C.; Bessa, V.; Mesquita, R.; Brix, H.; Rangel, A.; Castro, P. Constructed wetlands with a polyculture of ornamental plants for wastewater treatment at a rural tourism facility. Ecol Eng. 2015, 79, 1-7; DOI: https://doi.org/10.1016/j.ecoleng.2015.03.001

92. García, M.; Soto, F.; González, JM.; Bécares, E. A comparison of bacterial removal efficiencies in constructed wetlands and algae-based systems. Ecol. Eng. 2008, 32(3), 238-243; DOI: https://doi.org/10.1016/j.ecoleng.2007.11.012

93. Ansola, G.; González, JM.; Cortijo, R.; de Luis, E. Experimental and full-scale pilot plant constructed wetlands for municipal wastewaters treatment. Ecol. Eng. 2003, 21(1), 43-52; DOI: https://doi.org/10.1016/j.ecoleng.2003.08.002

94. Weragoda, SK.; Jinadasa, KBSN.; Zhang, DQ.; Gersberg, RM.; Tan, SK.; Ng, WJ. Tropical application of floating treatment wetlands. Wetlands 2012, 32(5), 955-961; DOI: https://doi.org/10.1007/s13157-012-0333-5

95. Chyan, JM.; Lu, CC.; Shiu, RF.; Bellotindos, L. Purification of landscape water by using an innovative application of subsurface flow constructed wetlands. Environ Scie Pollut Res. 2016, 23, 535-545; DOI: https://doi.org/10.1007/s11356-015-5265-

96. Chyan, JM.; Jhu, YX.; Chen, I.; Shiu, R. Improvement of nitrogen removal by external aeration and intermittent circulation in a subsurface flow constructed wetland of landscape garden ponds. Proc Saf Environ Prot. 2016, 104, 587-597; DOI: https://doi.org/10.1016/j.psep.2016.02.016 
97. Sirianuntapiboon, S.; Jitvimolnimit, S. Effect of plantation pattern on the efficiency of subsurface flow constructed wetland (SFCW) for sewage treatment. Afr J Agric Res. 2007, 2, 447-454; DOI: 10.5897/AJAR

98. Sohsalam, P.; Englande, A.; Sirianuntapiboon, S. Seafood wastewater treatment in constructed wetlands: Tropical case. Bioresour Technol. 2008, 99, 1218-1224; DOI: https://doi.org/10.1016/j.biortech.2007.02.014

99.Konnerup, D.; Koottatep, T.; Brix, H. Treatment of domestic wastewater in tropical subsurface flow constructed wetlands planted with Canna and Heliconia. Ecol Eng. 2009, 35(2), 248-257; DOI: https://doi.org/10.1016/j.ecoleng.2008.04.018

100. Kantawanichkul, S.; Karnchanawong, S.; Jing, SH. Treatment of fermented fishproduction wastewater by constructed wetland system in Thailand. Chiang Maij Sci. 2009, 36(2), 149-157; DOI: Avaidable Online: http://www.thaiscience.info/journals/Article/CMJS/10905526.pdf.Access ed on 20 September 2018.

101. Brix, H.; Koottatep, T.; Fryd, O.; Laugesen CH. The flower and the butterfly constructed wetland system at Koh Phi Phi - system design and lessons learned during implementation and operation. Ecol Eng. 2011, 37(5), 729-735; DOI: https://doi.org/10.1016/j.ecoleng.2010.06.035

102. Torit, J.; Siangdung, W.; Thiravetyan, P. Phosphorus removal from domestic wastewater by Echinodorus cordifolius L. J Environ Sci Health, Part A. 2012, 47, 794-800; DOI: https://doi.org/10.1016/j.ecoleng.2010.06.035

103. Tunçsiper, B.Nitrogen removal in a combined vertical and horizontal subsurface-flow constructed wetland system. Desalination.2009, 247(1-3), 466-475; DOI: https://doi.org/10.1016/j.desal.2009.03.003

104. Neralla, S.; Weaver, RW.; Lesikar, BJ.; Persyn, RA. Improvement of domesticwastewater quality by subsurface flow constructed wetlands. Bioresour Technol. 2000, 75 (1), 19-25; DOI: https://doi.org/10.1016/S0960-8524(00)00039-0

105. Polomski, RF.; Bielenberg, DG.; Whitwell, T. Nutrient Recovery by Seven Aquatic Garden Plants in a Laboratory-scale Subsurface-constructed Wetland. Hortscience. 2007, 42(7), 1674-1680; DOI: Avaidable online: http://hortsci.ashspublications.org/content/42/7/1674.short. Access on 12 July 2018

106. Zachritz, WH.; Hanson, AT.; Sauceda, JA.;Fitzsimmons, KM. Evaluation of submerged surface flow (SSF) constructed wetlands for recirculating tilapia production systems. Aquacult Eng. 2008, 39, 16-23; DOI: https://doi.org/10.1016/j.aquaeng.2008.05.001

107. Chen, Y.; Bracy, R.; Owings, A. Nitrogen and phosphorous removal by ornamental and wetland plants in a greenhouse recirculation research system. HortScience. 2009, 44(6), 1704-1711; DOI: Avaidable online: http://hortsci.ashspublications.org/content/44/6/1704.short.Access ed on 14 July 18.

108. Konnerup, D.; Trang, NTD.; Brix, H. Treatment of fishpond water by recirculating horizontal and vertical flow constructed wetlands in the tropics? Aquaculture 2011, 313(1-4), 57-64; DOI: https://doi.org/10.1016/j.aquaculture.2010.12.026

109. McKinlay, RG.;Kasperek, K. Observations on decontamination of herbicide polluted water by marsh plant system. Water Res. 1999, 33, 505-511; DOI: https://doi.org/10.1016/S0043-1354(98)00244-9

110. Gersberg, RM.; Elkins, BV.; Lyon, SR.; Goldman, CR. Role of aquatic plants in wastewater treatment by artificial wetlands. Water Res 1986, 20(3), 363-368; DOI: https://doi.org/10.1016/B978-0-08-040784-5.50035-8

111. Duarte, A.; Canais-Seco, T.; Peres, J.; Bentes, I.; Pinto, J. Sustainability indicators of subsusrface flow constructed wetlands in Portuguese small communities. WSEAS trans Environ Develop. 2010, 9(6), 625-634; DOI: http://hdl.handle.net/1822/16373

112. Patra, B.; Acharya, L.; Mukherjee, AK.; Panda, MK.; Panda, CP. Molecular characterization of ten cultivars of Canna lilies (Canna Linn.) using PCR based molecular markers (RAPDs and ISSRs). Int J Integr Biol. 2008, 2, 129-137; Avaidable

Online: https://www.researchgate.net/profile/Pratap Panda/publication/26516984 Molecular characterization of ten cultivars of_Canna_lilies_Canna_Linn_using_PCR_based_molecular_markers_RAPDs and_ISSRs/links/09e41 505a02434ad4b000000.pdf.Access on 13 August 2018

113. Gupta, A.; Maurya, R.; Roy, RK.; Sawant, S.; Yadav, H. AFLP based genetic relationship and population structure analysis of Canna-An ornamental plant. Sci. Hortic. 2013, 154, 1-7; DOI: https://doi.org/10.1016/j.scienta.2013.02.005. 
114. Kulig, M.; Wronski, M.; Ostafin, K. The characteristics of flowers, and of clumps of selected iris species and varieties, from the Limniris section. Horticult. Landsc. Architect.2013, 34, 3-12; DOI: Avaidable Online: https://mrec.ifas.ufl.edu/grapes/genetics/Selected-Publications/B\%20\%20PlantSci\%20Promoter\%208-4-12.pdf. Access On: 20 September 2018.

115. Kulig, M. Characteristics of flowers of selected iris species and varieties from Limniris section.EJPAU.2012, 15(1), \#04. http://www.ejpau.media.pl/volume15/issue1/art-04.html

116. Kress, WJ. The diversity and distribution of Heliconia (Heliconiaceae) in brazil). Acta Bot Bras.1990, 4(1), 159-167; DOI: Avaidable Online: http://www.ejpau.media.pl/volume15/issue1/index_stitle_sabs.html. Access on 28 July 18.

117. Maas, PJM. Renealmia (Zingiberaceae - Zingiberoideae); Costoideae (Zingiberaceae). FI. Neotropica Monogr 1977, 18, 1-218; DOI: https://www.jstor.org/stable/4393712.

118. Bogner, J.; Nicolson, DH. A revised classification of Araceae with dichotomous keys.Willdenowia.1991, 21, 35-50; DOI: https://www.jstor.org/stable/3996587

119. Rodríguez, M.; Brisson, J. Pollutant removal efficiency of native versus exotic common reed (Phragmites australis) in North American treatment wetlands. Ecol Eng. 2015, 74, 364-370; DOI: https://doi.org/10.1016/j.ecoleng.2014.11.005

120. Zhang, D.; Jinadasa, K.; Gersberg, R.; Liu, Y.; Ng, W.; Tan, S. Application of constructed wetlands for wastewater treatment in developing countries - A review of recent developments. J Environ Manag. 2014, 141, 116-131; DOI: https://doi.org/10.1016/j.jenvman.2014.03.015.

121. Zhang, D.; Jinadasa, K.; Gersberg, R.; Liu, Y.; Tan, S.; Ng, W. Application of constructed wetlands for wastewater treatment in tropical and subtropical regions (2000-2013). J Environ Sci. 2015, 30, 30-46; DOI: https://doi.org/10.1016/j.jes.2014.10.013

122. Frazer-Williams, R. A review of the influence of design parameters on the performance of constructed wetlands. J Chem Eng. 2010, 25(1), 29-42; DOI: http://dx.doi.org/10.3329/jce.v25i0.7237

123. Machado, A. I.; Beretta, M.; Fragoso, R.; Duarte, E. Overview of the state of the art of constructed wetlands for decentralized wastewater management in Brazil. J. Environ. Manage. 2017, 187, 560-570; DOI: https://doi.org/10.1016/j.jenvman.2016.11.015 